Proceeding The $1^{\text {ST }}$ Gorontalo Internasional Nursing $\quad$ ISBN : 978-602-6204-10-3

Conference 2017

Universitas Negeri Gorontalo

\title{
Diabetes Mellitus, Diabetes Self Management Education (DSME), and Self Care Diabetik
}

\author{
Andi Akifa Sudirman \\ ${ }^{1)}$ Staf Dosen Program Studi Ilmu Keperawatan Universitas Muhammadiyah Gorontalo \\ andiakifasudirman@gmail.com
}

\begin{abstract}
ABSTRAK
Diabetes Self Management Education (DSME) which integrates the four pillars of Diabetes Mellitus Management independently emphasize the behavioral interventions which help people with diabetes to change their lifestyles in terms of diabetic self care. The implementation of DSME related to the continual education covers the basic concepts of DSME itself, diet time arrangement, physical activity, foot care and exercises for people with diabetes. The objective of this research was to find out the effectiveness of Diabetes Self Management Education (DSME) group method on the type 2 Diabetes Mellitus Outpatient at Public Health Center Gorontalo Regency. The design of this research was Quasi Experimental Design with Pre-Test and Post Test. The samples were taken by using cluster sampling technique. The number of samples were 24 which was divided into two groups, 12 people of control group and 12 people of intervention group. The data were analized by using paired t test. The result of this research showed that there were significant differences of diabetic self care in type 2 Diabetes Mellitus patients after the implementation of Diabetes Self Management Education (DSME) group method with $p$ value $=0,00$. In conclusion, the program of DSME that related to diabetic self care can be applied systematically and sustainably as the nursing intervention to patients by using proper media and method of education. By applying the method and media properly, people with diabetes can control and prevent the type 2 Diabetes Mellitus complication.
\end{abstract}

Key Words : Diabetes Mellitus, Diabetes Self Management Education (DSME), Diabetic Self Care 


\section{Introduction}

Diabetes mellitus (DM) merupakan penyakit kronis progresif yang ditandai dengan ketidakmampuan tubuh untuk melakukan metabolisme karbohidrat, lemak dan protein, mengarah ke hiperglikemia (kadar glukosa darah tinggi). Walaupun hiperglikemia memainkan sebuah peran penting dalam perkembangan komplikasi terkait DM, kadar yang tinggi dari glukosa darah hanya satu komponen dari proses patologis dan manifestasi klinik yang berhubungan dengan DM. Proses patologis dan faktor risiko lain adalah penting dan merupakan faktor-faktor independen. Diabetes mellitus dapat berhubungan dengan komplikasi serius, namun orang dengan DM dapat mengambil cara-cara pencegahan untuk mengurangi kemungkinan kejadian tersebut (Black Joyce \& Hawks, 2014).

Berbagai penelitian epidemiologi menunjukkan adanya kecenderungan peningkatan angka insidens dan prevalensi DM tipe 2 diberbagai penjuru dunia. WHO dan International Diabetes Federation (IDF) memprediksi kenaikan jumlah penyandang DM meskipun terdapat perbedaan angka prevalen, laporan keduanya menunjukkan adanya peningkatan jumlah penyandang DM sebanyak 2-3 kali lipat pada tahun 2030. Peningkatan jumlah penderita yang sangat besar dan merupakan beban yang sangat berat ditangani sendiri oleh dokter spesialis/subspesialis bahkan oleh semua tenaga kesehatan yang ada. Mengingat DM akan memberikan dampak terhadap kualitas sumber daya manusia dan peningkatan biaya kesehatan yang cukup besar, semua pihak baik masyarakat maupun pemerintah seharusnya ikut serta dalam usaha penanggulangan DM, khususnya dalam upaya pencegahan (PERKENI, 2011).

Berdasarkan data Dinas Kesehatan Provinsi Gorontalo tahun 2013 total kasus lama sejumlah 1918 jiwa, kasus baru 878 jiwa dan kematian 68 jiwa. Data tahun 2014 terjadi peningkatan kasus lama sejumlah 2897 jiwa, kasus baru 1457 jiwa dan kematian 98 jiwa di Provinsi Gorontalo. Sedangkan untuk wilayah Kabupaten Gorontalo menduduki peringkat pertama pada tahun 2013 dengan jumlah kasus lama 951 jiwa, kasus baru 299 jiwa dan kematian 41 jiwa, dan pada tahun 2014 terjadi peningkatan jumlah kasus lama 1403 jiwa dan kasus baru meningkat menjadi 538 jiwa dan jumlah kematian 48 jiwa. Data Dinas Kesehatan Kabupaten Gorontalo didapatkan data tahun 2015 jumlah kasus lama berjumlah 1854 jiwa dan jumlah kasus baru diabetes melitus berjumlah 977 jiwa sehingga jika data tersebut dibandingkan dari data DIKES Provinsi Gorontalo tahun 2014 menunjukkan kasus lama mengalami peningkatan $32,15 \%$ dan temuan kasus baru diabetes melitus juga menunjukkan mengalami peningkatan mencapai 44,9\% . Sedangkan data periode Juli 2016 untuk wilayah Kabupaten Gorontalo telah tercatat 273 kasus baru dan 812 kasus lama.

$\begin{array}{crr}\text { Diabetes melitus } & \text { merupakan } \\ \text { penyakit yang progresif } & \text { sehingga }\end{array}$ menyebabkan berbagai komplikasi baik akut maupun kronis jika tidak dikelola dengan baik akan dapat mengakibatkan terjadinya berbagai penyulit menahun, seperti penyakit serebrovaskular, penyakit jantung koroner, penyakit pembuluh darah tungkai, gangguan pada mata, ginjal dan syaraf. Penyandang diabetes melitus mempunyai risiko 2 kali lebih besar untuk mengalami penyakit jantung koroner dan penyakit pembuluh darah otak, 5 kali lebih mudah menderita ulkus/gangren, 7 kali lebih mudah mengidap gagal ginjal terminal, dan 25 kali lebih mudah mengalami kebutaan akibat kerusakan retina daripada pasien non diabetes. Usaha untuk menyembuhkan kembali menjadi normal sangat sulit jika sudah terjadi penyulit, karena kerusakan yang terjadi 
Proceeding The $1^{\text {ST }}$ Gorontalo Internasional Nursing $\quad$ ISBN : 978-602-6204-10-3

Conference 2017

Universitas Negeri Gorontalo

umumnya akan menetap. Usaha pencegahan diperlukan lebih dini untuk mengatasi penyulit tersebut dan diharapkan akan sangat bermanfaat untuk menghindari terjadinya berbagai hal yang tidak menguntungkan. Tanpa intervensi yang efektif, DM tipe 2 akan meningkat, yang disebabkan karena usia harapan hidup yang bertambah, berkurangnya kematian akibat penyakit infeksi dan meningkatnya faktor risiko oleh karena pola hidup dan pola makan yang salah, kegemukan, kurangnya aktivitas fisik, serta stress (PERKENI, 2011).

Sejalan dengan permasalahan tersebut pemerintah telah melakukan berbagai upaya dan program pengelolaan penderita DM bekerja sama dengan salah satu asuransi kesehatan meluncurkan program pengelolaan penyakit kronis Diabetes Melitus Tipe 2 (PPDM tipe 2) yang merupakan suatu sistem tata laksana pelayanan kesehatan hidup yang optimal secara mandiri dengan tujuan menurunkan komplikasi dan mencapai kualitas hidup yang baik dengan pemanfaatan biaya yang efektif dan rasional. Kemudian BPJS (Badan Penyelenggara Jaminan Sosial) Kesehatan mengintegrasikan program PPDM Tipe 2 menjadi salah satu program rutinnya. program tersebut berganti nama menjadi PROLANIS (Program Pengelolaan Penyakit Kronis) dengan sasaran khususnya DM Tipe 2 dan hipertensi. Kabupaten Gorontalo juga menjadi pelaksana program PROLANIS termasuk Puskesmas dan praktek dokter bersama namun pelaksanaannya belum optimal. Terlihat dari berbagai bentuk kegiatan PROLANIS berupa penyuluhan kesehatan, pemeriksaan kesehatan, senam prolanis dan pemberian obat yang dilaksanakan dikarenakan keterbatasan tenaga dan waktu pelaksana prolanis di Puskesmas. Kemudian tatalaksana kegiatan antar Puskesmas sekabupaten Gorontalo bervariasi dikarenakan tidak ada Standar Operasional Prosedural (SOP) untuk PROLANIS. Dan berdasarkan evaluasi peneliti target kepesertaan prolanis masih belum tercapai, hal ini dibuktikan dari data Tahun 2015 jumlah kasus lama 1800 kasus sedangkan jumlah kunjungan kasus lama periode Juli 2016 hanya 812 kasus sehingga disimpulkan target kepersertaan Prolanis belum memenuhi target.

Perawatan diri (self care) merupakan suatu tindakan individu yang terencana dalam rangka mengendalikan penyakitnya untuk mempertahankan dan meningkatkan status kesehatan dan kesejahteraannya (Orem, 2001). Perilaku perawatan diri yang baik dapat diadaptasi melalui bantuan dan petunjuk dari tenaga kesehatan profesional. Hal ini dapat dilakukan dengan melakukan perawatan diri yang dilakukan dan dikembangkan oleh seseorang dengan menggabungkan keterampilan perawatan diri dan keterampilan dalam proses pengambilan keputusan yang berhubungan dengan kesehatannya. (Tomey \& Alligood, 2006).

The American Diabetes Association (ADA, 2016) merekomendasikan kegiatan penyuluhan untuk menjaga agar pengetahuan tentang diabetes tetap dimiliki oleh pasien. Manajemen diabetes mandiri ini berbeda dari pendidikan DM yang tradisional. Manajemen mandiri lebih mengarah pada tindakan nyata dan perubahan perilaku. Oleh sebab itu dalam upaya memberikan DSME maka setiap sesi difokuskan dalam mengidentifikasi perilaku tertentu dan memberikan tujuan yang jelas yang nantinya akan diadopsi oleh penyandang DM, yang akhirnya dapat mengoptimalkan kontrol glikemik, menghindari komplikasi akut maupun kronis dan mengoptimalkan kualitas kehidupan (Funnel, 2010).

$$
\text { Diabetes Self Management }
$$

Education (DSME) yang mengintegrasikan empat pilar penatalaksanaan DM menekankan intervensi perilaku secara mandiri. Para peneliti telah mengidentifikasi beberapa keterampilan khusus yang disebut manajemen diri yang membantu merubah berbagai faktor yang berhubungan dengan kepatuhan yang pabla 
Proceeding The $1^{\text {ST }}$ Gorontalo Internasional Nursing $\quad$ ISBN : 978-602-6204-10-3

Conference 2017

Universitas Negeri Gorontalo

akhirnya dapat membantu merubah gaya hidup. DSME menggunakan metode pedoman, konseling, dan intervensi perilaku untuk meningkatkan pengetahuan mengenai diabetes dan meningkatkan keterampilan individu dan keluarga dalam mengelola penyakit DM. Metode ini memfasilitasi pengetahuan, keterampilan dan kemampuan perawatan mandiri (self care behavior) yang sangat dibutuhkan oleh penderita diabetes. Kemampuan untuk melakukan perawatan diri berjalan melalui proses belajar dengan pemberian pengetahuan dan latihan (Funnel, 2010).

Pendekatan pendidikan kesehatan dengan metode DSME tidak hanya sekedar menggunakan metode penyuluhan baik langsung maupun tidak langsung namun telah berkembang dengan mendorong partisipasi dan kerjasama diabetesi dan keluarganya. Proses kelompok merupakan salah satu strategi edukasi dengan beberapa kelebihan diantaranya pendidikan lebih aktif, interaksi lebih dinamis, tercipta sosial model, dan pembelajaran berorientasi pada masalah (Mensing, Noris, 2009). Program pendidikan kesehatan DM belum banyak dikembangkan di wilayah komunitas, padahal pasien DM banyak berada di lingkungan komunitas, juga diketahui dari fenomena pelaksanaan edukasi sering mengalami beberapa kendala khususnya di tatanan pelayanan primer (Puskesmas) terutama waktu, tenaga dan kemampuan perawat memberikan edukasi. Akibanya pasien tidak mendapatkan informasi yang cukup terkait penyakit.

\section{Method}

Penelitian ini dilakukan di Puskesmas Limboto untuk kelompok kontrol dan Puskesmas Limboto Barat untuk kelompok intervensi dengan desain quasi eksperimen melalui pendekatan desain pre post test group design. Desain ini digunakan untuk membandingkan hasil intervensi penerapan Diabetes Self
Management Education (DSME) metode kelompok terhadap self care diabetik pada pasien diabetes melitus tipe 2. Data Primer dikumpulkan dengan teknik probability sampling melalui teknik cluster sampling. Teknik sampel dilakukan melalui dua tahap yaitu tahap pertama menentukan sampel lokasi Puskesmas dari 21 Puskesmas Sekabupaten Gorontalo dengan teknik pengundian sehingga didapatkan Puskesmas Limboto Barat sebagai kelompok kontrol dan Puskesmas Limboto sebagai kelompok kasus selanjutnya tahap dua adalah menentukan target respondennya untuk kedua puskesmas tersebut sehingga didapatkan jumlah sampel 24 orang untuk dua kelompok, 12 orang kelompok kontrol dan 12 orang kelompok intervensi pada pasien rawat jalan diabetes mellitus tipe 2 yang tidak memiliki keterbatasan fisik, kognitif dan mental (penurunan penglihatan, pendengaran, memori), komplikasi yang dapat mengganggu penelitian (CHF, GGK, dll) dan bersedia mengikuti seluruh rentetan kegiatan DSME. Waktu Penelitian dilaksanakan pada Oktober 2016 - Februari 2017. Uji Statistik yang dilakukan peneliti adalah dengan menggunakan uji dependen t-test/uji paired t test.

Langkah capaian penelitian ini yaitu pemilihan responden yang memenuhi kriteria inklusi dan kriteria inklusi. Kemudian dilakukan pengumpula data dengan kuisioner data demografi pada variabel konfounding diantaranya : umur, jenis kelamin, tingkat pendidikan, lama DM, dukungan keluarga, stress dan edukasi sebelumnya. Kedua kelompok (kontrol dan intervensi) dilakukan pengukuran awal pre test (self care diabetik) pada minggu I dilokasi masingmasing. Kelompok kontrol di Puskesmas Limboto dengan $\mathrm{n}=12$ sampel tidak diberikan informasi terstruktur melainkan mengikuti rutinitas program yang diterapkan di Puskesmas tersebut. Kelompok intervensi di Puskesmas Limboto Barat dengan $\mathrm{n}=12$ samp 1 , 
Proceeding The $1^{\text {ST }}$ Gorontalo Internasional Nursing $\quad$ ISBN : 978-602-6204-10-3

Conference 2017

Universitas Negeri Gorontalo

diberikan informasi terstruktur (DSME) sebanyak 4 kali pertemuan selama 1 bulan. Kemudian kedua kelompok (kontrol dan intervensi) dilakukan pengukuran akhir post test pada minggu VI dilokasi masing-masing.

Instrumen variabel self care yang digunakan adalah modifikasi kuisioner yang berasal dari The Summary of Diabates Self Care Activities (SDSCA) yang dikembangkan oleh Toobert et al (2000). Kuisioner ini terdiri dari 14 pertanyaan terkait dengan aktivitas self care diabetes pada penderita DM tipe 2 yang meliputi diet (pengaturan pola makan), latihan fisik/aktivitas, monitoring gula darah, pengobatan, perawatan kaki dan merokok. Untuk instrument nomer 1-14 terdiri jumlah hari perminggu dengan skala jawaban 0-7. Untuk pernyataan positif skor yang diberikan yaitu 0 hari (skor=0), 1 hari (skor=1), 2 hari (skor=2), 3 hari (skor=3), 4 hari (skor=4), 5 hari (skor $=5$ ), 6 hari (skor=6) dan 7 hari (skor=7). Sedangkan untuk pernyataan negatif, pada pertanyaan no. 5-6 skor yang diberikan yaitu 0 hari (skor=7), 1 hari (skor=6), 2 hari (skor=5), 3 hari (skor=4), 4 hari (skor=3), 5 hari (skor=2), 6 hari (skor=1) dan 7 hari (skor=0). Hasil pengukuran self care diabetik dalam bentuk interval dengan menghitung jumlah skor kumulatif self care diabetik dibagi dengan jumlah item pertanyaan. Nilai/skor terendah 0 dan nilai/skor tertinggi 7 , selanjutnya dianalisis untuk mengetahui nilai mean, standar deviasi, min-max dan $95 \%$ CI. Instrumen ini memiliki nilai kevaliditasnya yang tinggi namun karena diadopsi dari bahasa Inggris yang peneliti terjemahkan kedalam bahasa Indonesia sehingga memerlukan uji validitas dan reabilitas kembali yang dilaksanakan di Puskesmas Telaga Kabupaten Gorontalo dengan jumlah responden 15 orang. Dari 14 pertanyaan (P1-P14) didapatkan $\mathrm{r}$ hasil > dari $r$ tabel $=0,514(\mathrm{df}=13)$, sehingga semua pertanyaan dinyatakan valid.
Sedangkan hasil analisa uji reabilitas didapatkan nilai $r$ alpha $(r=0,983)>r$ tabel $(\mathrm{r}=0,514) \quad$ sehingga didapatkan kesimpulan semua pertanyaan reliabel.

\section{Result and Discussion}

Tabel I

Distribusi Responden Menurut Karakteristik Variabel

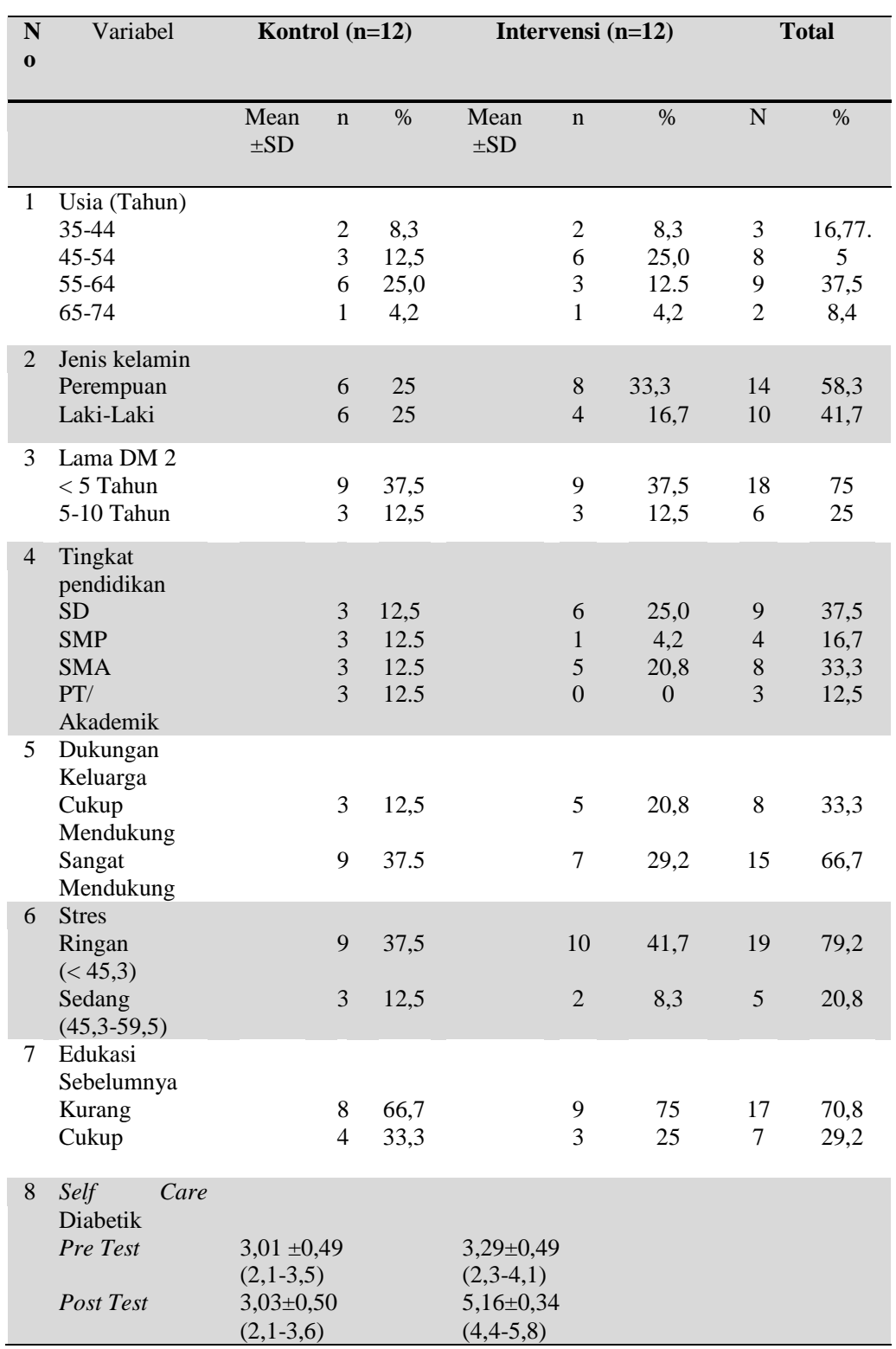

Sumber : Data Primer, Oktober 2016 - Februari 2017 
Proceeding The $1^{\text {ST }}$ Gorontalo Internasional Nursing $\quad$ ISBN : 978-602-6204-10-3

Conference 2017

Universitas Negeri Gorontalo

Tabel $\quad 3.1 \quad$ menunjukkan karakteristik responden dari 24 responden berdasarkan usia terbanyak berada pada kelompok umur 55-64 tahun yakni 9 orang $(37,5 \%)$, jenis kelamin terbanyak perempuan yakni 14 orang $(58,3 \%)$, dengan lama menderita DM tipe $2(<5$ tahun) sebanyak 18 orang ( $75 \%)$, sebagian besar memiliki tingkat pendidikan SD yakni 9 orang $(37,5 \%)$, dengan dukungan keluarga mayoritas sangat mendukung yakni 15 orang $(66,7 \%)$, dengan tingkat stress ringan sebanyak 19 orang $(79,2 \%)$ dan sebagian besar kurang terpapar edukasi sebelumnya yakni 17 orang (70,8\%) baik pada kelompok kontrol maupun intervensi.

Sedangkan hasil pengukuran pre test rata-rata Self care diabetik responden pada kelompok kontrol adalah 3,01, dengan standar deviasi 0,49. Nilai terendah 2,1 dan tertinggi 3,5. Dan hasil pengukuran pre test rata-rata self care diabetik responden pada kelompok intervensi adalah 3,29 dengan standar deviasi 0,49. Self care diabetik terendah yakni 2,3 dan tertinggi 4,1. Berdasarkan hasil pengukuran post test rata-rata self care diabetik pada kelompok kontrol adalah 3,03, dengan standar deviasi 0,50. Self care diabetik terendah yakni 2,1 dan tertinggi 3,6. Sedangkan self care diabetik responden pada kelompok intervensi adalah 5,16 dengan standar deviasi 0,34. Self care diabetik terendah yakni 4,4 dan tertinggi 5,8.

Tabel 2

Hasil Analisa Bivariat Perbedaan Self Care Diabetik Pada Pasien Rawat Jalan Diabetes Mellitus Tipe 2 Sebelum Dan Sesudah Perlakuan

\begin{tabular}{llllllll}
\hline $\mathbf{N}$ & Kelompok & N & Mean & SD & SE & t & P Value \\
o & & & & & & & \\
\hline 1 & Kontrol & & & & & & \\
& Pre test & 12 & 3,00 & 0,49 & 0,14 & - & 0,60 \\
& Post test & 12 & 3,03 & 0,50 & 0,14 & 0,540 & \\
\hline 2 & Intervensi & & & & & & 0,00 \\
& Pre Test & 12 & 3,29 & 0,49 & 0,13 & - & \\
& Post test & 12 & 5,16 & 0,34 & 0,09 & 14,25 & \\
\hline
\end{tabular}

Sumber : Data Primer, Oktober 2016 - Februari 2017

Berdasarkan dari hasil penelitian didapatkan rata-rata self care diabetik pada pengukuran setelah (post test) tanpa mendapat perlakuan DSME pada kelompok kontrol lebih tinggi dari pengukuran sebelum (pre test) pada kelompok kontrol. Pada penelitian didapatkan peningkatan rata-rata namun tidak signifikan pada pengukuran post test tanpa pemberian Self Management Education (DSME) metode kelompok dimana nilai $\mathrm{p}>0,05$ ( $\mathrm{p}$ value $=0,60$ pada $\alpha=0,05$ ) sehingga didapatkan kesimpulan bahwa tidak terdapat perbedaan self care diabetik yang bermakna pada pengukuran post test tanpa pemberian DSME pada kelompok kontrol. Sejalan dari hasil penelitian Rondhianto (2012) menunjukkan pada kelompok kontrol mengalami peningkatan self care behavior dengan nilai $t$ hitung $(-10,694)$ dan $p$ $0,00<0,05(\alpha)$ yang artinya walaupun pada kelompok kontrol tidak mendapatkan intervensi, namun terdapat perbedaan self care behavior pada saat pre test dan pos test, dengan nilai $\mathrm{t}$ negative yang menunjukkan bahwa nilai pre test lebih rendah dari pada nilai post test.

Hal ini sesuai pendapat Ellis didalam Atak (2010) yang menyatakan bahwa pasien yang diberikan informasi tentang penyakit dan bagaimana perawatannya akan menunjukkan hasil yang positif dalam pengelolaan penyakitnya. Pendidikan kesehatan yang rendah akan berdampak terhadap kemampuan pengelolaan DM secara mandiri (self care diabetik) oleh pasien dan keluarga sehingga dapat mengakibatkan tingginya angka rawat ulang dan komplikasi yang dialami oleh pasien. Asumsi peneliti menyebutkan bahwa peningkatan self care diabetik yang terjadi pada kelompok kontrol, walaupun lebih rendah dari pada kelompok perlakuan kemungkinan disebabkan kelompok 
Proceeding The $1^{\mathrm{ST}}$ Gorontalo Internasional Nursing $\quad$ ISBN : 978-602-6204-10-3

Conference 2017

Universitas Negeri Gorontalo

kontrol juga mendapatkan pendidikan kesehatan melalui program PROLANIS yang rutin dihadiri responden di poliklinik lokasi penelitian tersebut.

Selanjutnya Self care diabetik pada kelompok intervensi sebelum dan sesudah perlakuan berdasarkan dari hasil penelitian didapatkan rata-rata self care diabetik pada pengukuran setelah (post test) pemberian Diabetes Self Management Education (DSME) metode kelompok pada kelompok intervensi lebih tinggi dari pengukuran sebelum (pre test) pemberian DSME pada kelompok intervensi. Hasil analisis lebih lanjut menyimpulkan bahwa terdapat perbedaan self care diabetik yang bermakna pada pengukuran (post test) pemberian Diabetes Self Management Education (DSME) metode kelompok pada kelompok intervensi dimana nilai $\mathrm{p}<$ $0,05(\mathrm{p}$ value $=0,00$ pada $\quad \alpha=$ $0,05)$. Hal ini membuktikan bahwa self care diabetik dipengaruhi oleh Diabetes Self Management Education (DSME) metode kelompok yang diberikan oleh peneliti. Sejalan dari hasil penelitian Rondhianto (2012) melakukan penelitian pada 30 pasien DM tipe 2 yang terdiri dari 15 responden kontrol dan 15 responden intervensi yang diberikan perlakuan penerapan DSME terstruktur pada discharge planning. Hasil penelitian tersebut menunjukkan pada kelompok intervensi mengalami peningkatan self care behavior yang signifikan, dimana didapatkan peningkatan self care behavior pada kelompok intervensi lebih tinggi dari kelompok kontrol.

Goldstein (2002) di dalam Wu (2007) menyebutkan bahwa perawatan secara mandiri sangat tergantung kepada pasien dalam membuat keputusan dan penilaian dalam menjalani hidupnya sehari-hari sehingga penatalaksanaan diabetes secara komprehensif dapat dilaksanakan. Perawatan mandiri pasien sangat tergantung pada pendidikan kesehatan yang mereka peroleh, pendayagunaan dan kemampuan monitoring terhadap perawatan diri mereka sendiri. Sehingga membantu pasien DM mengubah perilakunya secara signifikan akan meningkatkan self management sehingga outcome yang diharapakan berupa pencegahan komplikasi dan kualitas hidup yang baik dapat dicapai. Menurut Noris (2002) intervensi DSME sangat bermanfaat dalam meningkatkan pengetahuan diabetesi tentang DM dan pengelolaannya serta meningkatkan status psikososial diabetesi berkaitan dengan kepercayaan dan sikap terhadap program pengobatannya dan mekanisme koping. Diabetesi yang diberikan pendidikan dan pedoman dalam perawatan mandiri akan meningkatkan pola hidupnya yang dapat mengontrol kadar glukosa darah dengan baik. Sejalan dengan itu Funnell et al (2007) menyatakan bahwa diabetes merupakan penyakit yang harus bisa di kelola secara mandiri (self care). Penyakit kronis seperti diabetes membutuhkan pendekatan yang berpusat pada pasien, yaitu berupa empowerment atau pemberdayaan pasien yang merupakan filosofi keperawatan yang menekankan pada pendekatan untuk memfasilitasi pasien mengarahkan dirinya sendiri dalam perubahan perilaku.

Hal ini bersesuaian dengan kerangka teori yang mendasari DSME yaitu autonomy support yang merupakan dukungan yang diberikan pemberi pelayanan kesehatan dalam memahami pasien DM, kebutuhan dan prioritasnya, perasaaan, dan menyediakan pilihan dalam pengelolaan mandiri, pemberian informasi yang relevan. Pemberi dukungan diharapkan tidak melakukan kontrol terhadap perilaku pasien, tetapi pasien melakukan kontrol terhadap perilaku berdasarkan kesadaran diri. Hasil penelitian ini mendukung penelitian yang dilakukan oleh Funnell dan Anderson (2003) didalam Funnell et al (2007) yang menunjukkan bahwa pasien DM yang mendapatkan dukungan motivasi autonomy melalui DSME menjadi termotivasi secara internal unt̄̄k 
Proceeding The $1^{\text {ST }}$ Gorontalo Internasional Nursing $\quad$ ISBN : 978-602-6204-10-3

Conference 2017

Universitas Negeri Gorontalo

melakukan perawatan secara mandiri (self care) dengan melakukan pengaturan regulasi tingkat kadar gula darah, perasaan lebih kompeten dalam monitoring kadar gula darah. Autonomy support dengan filosofi pemberdayaan di dalamnya membuat pengelolaan diabetes dapat dilakukan pasien secara mandiri. Hasil penelitian ini juga bersesuaian dengan penelitian yang dilakukan oleh Deakin (2005) di dalam Funnel (2010) menunjukkan bahwa DSME dapat meningkatkan perawatan mandiri pasien.

Program edukasi dengan metode kelompok memiliki beberapa kelebihan bila dibandingkan dengan pendekatan secara individu, kelebihan tersebut diantaranya pendidikan lebih aktif, interaksi lebih dinamis, terciptanya social model, dan pembelajaran berorientasi pada masalah (Mensing dan Norris, (2009). Program pendidikan kesehatan dengan menggunakan kelompok menyebabkan peningkatan status fisik maupun psikososial. Sejumlah studi telah meneliti efektifitas pendidikan kelompok. Intervensi pada pendidikan kelompok berfokus pada penyelesaian masalah dan majemen diri, terdapat banyak ide yang muncul serta sharing pengalaman, berlatih keterampilan berkomunikasi dan memberikan dukungan sosial. Bila dibandingkan dengan pendidikan secara individu, pendidikan secara kelompok memberikan dampak yang lebih baik dalam kapasitas psikososial. Juga systematic review yang dilakukan oleh Norris et al (2009) menemukan bahwa adanya dampak yang berbeda antara pendidikan yang dilakukan secara kelompok dan secara individu terutama yang terkait dengan pengontrolan diet dan aktifitas fisik dinilai lebih baik pada pendekatan kelompok. Adapun. Secara keseluruhan, pendidikan yang dilakukan secara kelompok dan individu efektif meningkatkan perawatan mandiri pasien diabetes, program edukasi yang dilakukan dengan kelompok umumnya biayanya lebih murah, kepuasan pasien lebih besar, dan sedikit lebih efektif untuk perubahan perilaku dan gaya hidup seperti diet dan aktivitas fisik. Asumsi peneliti menyebutkan bahwa diabetesi yang diberikan pendidikan kesehatan dan pedoman dalam perawatan diri dengan terstruktur dan bertahap akan mengubah pola hidupnya, sehingga dapat meningkatkan perilaku perawatan dirinya dengan baik. Kemampuan untuk melakukan perawatan diri berjalan melalui proses belajar dengan pemberian pengetahuan dan latihan Intervensi DSME yang diberikan kepada pasien dapat meningkatkan aspek kognisi dan afeksi diabetesi secara simultan akan mempengaruhi peningkatan perilaku sehat diabetesi. Perilaku sehat tersebut terdiri dari monitoring kadar glukosa darah secara mandiri, perencanaan makan (diet), latihan jasmani dan istirahat yang cukup, konsumsi obat glikemik dengan benar, dan perawatan kaki. Peningkatan self care diabetik pada kelompok perlakuan menjadi lebih tinggi dibandingkan kelompok kontrol, karena selama masa penelitian di Poliklinik Puskesmas lokasi penelitian responden mendapatkan pendidikan kesehatan tentang penyakitnya secara lebih terstruktur, yaitu melalui penerapan DSME metode kelompok. Hasil yang didapatkan mempertegas bahwa melalui pendidikan kesehatan dapat meningkatkan kemampuan seseorang untuk meningkatkan pengetahuan, keterampilan, dan sikap diri mereka. Dan selama proses dan setelah dilakukannya pendidikan kesehatan terjadi proses adopsi perilaku dari responden terkait tema edukasi yang diberikan yang mendukung perawatan diri mereka.

\section{Conclusion}

Berdasarkan hasil dan pembahasan diatas, maka dapat disimpulkan bahwa terdapat perbedaan self care diabetik pada pasien diabetes melitus tipe 2 sebelum dan sesudah penerapan Diabetes Self Management Education (DSME) metode kelompok pada kelompok intervensi. 8 


\begin{tabular}{l}
\hline Proceeding The $1^{\text {ST }}$ Gorontalo Internasional Nursing \\
Conference 2017 \\
Universitas Negeri Gorontalo \\
\hline
\end{tabular}

\section{Reference}

ADA, (2011), Standart of Medical Care in Diabetes 2011. Journal of Diabetes Care, Volume 34, Supplement 1, January 2011, 11-61, http://Spectrum.diabetesjournals.org/h ttp://care.diabetesjournals.org/content/ 34/Supplement 1/S11.

(2013), Standart of Medical Care in Diabetes 2013. Journal of Diabetes Care, Volume 36, Supplement 1, January 2013, 11-66, http://Spectrum.diabetesjournals.org/h ttp://care.diabetesjournals.org/content/ 36/Supplement_1/S11.

(2015),Foundations o Care: Education, Nutrition, Physical Activity, Smoking Cessation, Phychosocial Care, and Immunization, Journal of Diabetes Care, Volume 38, Supplement 1, January 2015, 20-30, http://Spectrum.diabetesjournals.org/h ttp://care.diabetesjournals.org/content/ 38/Supplement_1/S20.

Agrimon Oryzati Hilman et.al (2014), Exploring the Feasibility of Implementing Self-Management and Patient Empowerment Through a Structurd Diabetes Education Programme in Yogyakarta City Indonesia; A Pilot Cluster Randomised Controlled Trial, University of Adelaide, Philippines.

Alligood, M.R and Tomey, A.M.(2006); Nursing Theoriest and their work. St Luis : CV. Mosby Elsevier, Inc.

Atak, N., Tanju Gurkan, Kenan Kose (2010), The Effect of Education on Knowledge, Self Management and Self Efficacy with Type 2 Diabetes, Australian Journal of Advanced Nursing. 26 (2).

Black M. Joyce \& Hawks Hokanson Jane (2014), Keperawatan Medikal Bedah Manajemen Klinis untuk Hasil yang Diharapkan, Edisi 8-Buku 2, Elsevier, Singapore.
Dinas Kesehatan Provinsi Gorontalo (2014) Profil Kesehatan Provinsi Gorontalo Tahun 2014, Gorontalo.

Ditjen PP \& PL (2008), Petunjuk Teknis Pengukuran Faktor Risiko Diabetes Melitus, Jakarta :Departemen Kesehatan Republik Indonesia.

Funnel, M.M, et al (2007), From DSME to DSMS: Developing EmpowermentBased Diabetes Self-Management Support, Journal Diabetes Spectrum, Vol 20, Number 4, 221-226, http://spectrum.diabetesjournals.org/. (2010). National Standars for Diaetes Self-Management Education, Journal Diabetes Care Volume 33, Supplement 1, January 2010, 89-96.

Norris S.L, et al (2002). Increasing Diabetes Self-Management Education in Community Settings A systematic Review, American Journal of Preventive Medicine by Elsevier Science Inc, Volume 22, No. 4S, 2002, 39-50.

Notoatmodjo Soekidjo (2012), Metodologi Penelitian Kesehatan Ed. Rev. Rikena Cipta, Jakarta.

Nursalam (2008), Konsep dan Penerapan Metodologi Penelitian Ilmu Keperawatan : Pedoman Skripsi, Tesis dan Instrumen Penelitian Keperawatan, Salemba Medika, Surabaya.

Perkumpulan Endokrinologi Indonesia (2011) Konsensus Pengelolaan Diabetes Melitis Tipe 2.. Editor S.Soegondo, P. Soewondo, I. Subekti dkk, Jakarta.PB PERKENI.

Powers, M.A, et al (2015). Diabetes Self Management Education and Support in Type 2 Diabetes: A Joint Position Statement of the American Diabetes Association, the American Association of Diabetes Educators, and the Academy of Nutrition and Dietetics, 
Journal Diabetes Care Volume 38, Supplement 1, July 2015, 1372-1382.

Rodhianto (2012), Pengaruh Diabetes Self Management Education dalam Discharge Planning terhadap Self Care Behavior Pasien Diabetes Mellitus Tipe 2, Jurnal Keperawatan Soedirman (The Soedirman Journal of Nursing), Volume 7, No. 3 November 2012.

Sastroasmoro Sudigdo (2011), Dasar-Dasar Metodologi Penilitian Klinis, Sagung Seto, Jakarta.

Sigurdardottir, A.K. (2005). Self-care in Diabetes : Model of Faktor Affecting Self Care. Journal of Clinical Nursing, 14, 301-3014.

Sousa, V.D \& Zauszniewski, J.A. (2005). Toward a Theory of Diabetes Selfcare Management. The Journal of Theory Contruction \& Testing, 9 (2), 61-67

Smeltzer, Suzanne C. (2002). Brunner \& Suddarth's textbook of medical surgical nursing ed. 8/e, LippincottRaven Publishers, 227 East Washington Square, Philadelphia, U.S.A.

Sucipto Adi, et. al (2014), Efektivitas Konseling DM dalam Meningkatkan
Kepatuhan dan Pengendalian Gua Darah pada Diabetes Melitus Tipe 2, Muhammadiyah Journal Of Nursing.

Toobert, D.J, Hampson, S.E \& Glasgow, R.E (2000). The Summary of Diabetes Self-care Activities Measure, Diabetes Care, 23 (7), 943-950.Tomey, A.M, \& Alligod,M. R. (2006), Nursing Theorits and Their Work (4 ed), St.Louis : Mosby.

Yuan Chuang, et al (2014). Research Article The Effect of Diabetes SelfManagement Education on Body Weight, Glicemic Control, and Other Metabolic Markers in Patients with Type 2 Diabetes Mellitus, Journal of Diabetes Research, Volume 2014, Article ID 789761, 6 Pages. http://dx.doi.org/1-.1155/2014/789761.

Wu, S. F. (2007). Effectiveness of Self Management for Persons with type 2 diabetes following the Implementation of a Self Efficacy enhancing Intervention Program in Taiwan. Quensland University of Technology; Scholl of Nursing., http://eprints.qut.edu.au/.

Zahri Darni (2013), Faktor-faktor yang Berpengaruh Terhadap Kejadian Rawat Inap Ulang Pasien DM Tipe 2 Di RSUD Persahabatan, UMJ, Jakarta. 
Proceeding The $1^{\text {ST }}$ Gorontalo Internasional Nursing $\quad$ ISBN : 978-602-6204-10-3 Conference 2017

Universitas Negeri Gorontalo 